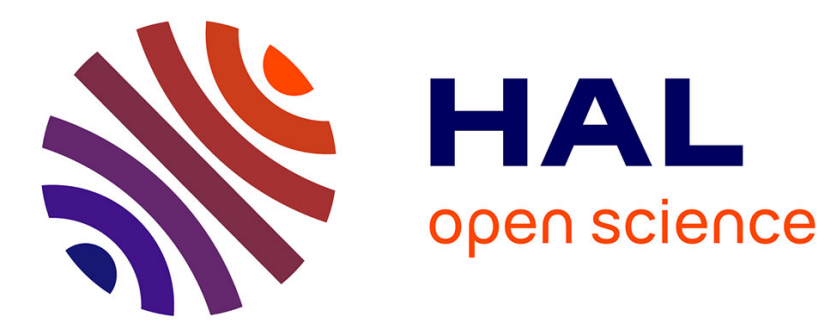

\title{
Landscape agronomy: a new field for addressing agricultural landscape dynamics
}

\author{
Marc Benoît, Davide Rizzo, Elisa Marraccini, Anna Camilla Moonen, \\ Mariassunta Galli, Sylvie Lardon, Hélène Rapey, Claudine Thenail, Enrico \\ Bonari
}

\section{To cite this version:}

Marc Benoît, Davide Rizzo, Elisa Marraccini, Anna Camilla Moonen, Mariassunta Galli, et al.. Landscape agronomy: a new field for addressing agricultural landscape dynamics. Landscape Ecology, 2012, 27 (10), pp.1385-1394. 10.1007/s10980-012-9802-8 . hal-01019874

\section{HAL Id: hal-01019874 https://hal.science/hal-01019874}

Submitted on 28 May 2020

HAL is a multi-disciplinary open access archive for the deposit and dissemination of scientific research documents, whether they are published or not. The documents may come from teaching and research institutions in France or abroad, or from public or private research centers.
L'archive ouverte pluridisciplinaire $\mathbf{H A L}$, est destinée au dépôt et à la diffusion de documents scientifiques de niveau recherche, publiés ou non, émanant des établissements d'enseignement et de recherche français ou étrangers, des laboratoires publics ou privés. 


\section{Landscape agronomy:}

\section{a new field for addressing agricultural landscape dynamics*}

Marc Benoît • Davide Rizzo • Elisa Marraccini • Anna Camilla Moonen •

Mariassunta Galli • Sylvie Lardon • Hélène Rapey • Claudine Thenail • Enrico Bonari

M. Benoît / D. Rizzo (Corresponding author)

INRA,UR 055 SAD ASTER, F-88500 Mirecourt, France

Phone: 0033 (0)3.29.38.55.00 | Fax: 0033 (0)3.29.38.55.19 | e-mail: ridavide@gmail.com

10

E. Marraccini

Scuola Superiore Sant'Anna, Istituto di scienze della vita, Land Lab, Piazza Martiri della Libertà, 33, I-56127 Pisa, Italy

INRA, UMR1273, UMR AgroParisTech/Inra/Irstea/VetAgroSup Mutations des Activités, des Espaces et des Formes d'Organisation dans les Territoires Ruraux, 24 avenue des Landais, Aubière Cedex F-63172, France

\section{A.C. Moonen / M. Galli / E. Bonari}

Scuola Superiore Sant'Anna, Istituto di scienze della vita, Land Lab, Piazza Martiri della Libertà, 33, I-56127 Pisa, Italy

\section{S. Lardon}

INRA \& AgroParisTech, UMR1273, UMR AgroParisTech/Inra/Irstea/VetAgroSup Mutations des Activités, des Espaces et des Formes d'Organisation dans les Territoires Ruraux, 24 avenue des Landais, Aubière Cedex F-63172, France

\section{H. Rapey}

Irstea, UMR1273, UMR AgroParisTech/Inra/Irstea/NetAgroSup Mutations des Activités, des Espaces et des Formes d'Organisation dans les Territoires Ruraux, 24 avenue des Landais, Aubière Cedex F-63172, France

\section{Thenail}

INRA, SAD-Paysage, 65, rue de Saint-Brieuc, CS 84215, F-35042 Rennes Cedex, France

\footnotetext{
"M. Benoît and D. Rizzo have equally contributed to the paper and are thus joined "lead authors".
} 


\section{Abstract}

Landscape dynamics increasingly challenge agronomists to explain how and why agricultural landscapes are designed and managed by farmers. Nevertheless, agronomy is rarely included in the wide range of disciplines involved in landscape research.

In this paper, we describe how landscape agronomy can help explain the relationship between farming systems and agricultural landscape dynamics. For this, we propose a conceptual model of agricultural landscape dynamics (ALaDyn) that illustrates the specific contribution of agronomy to landscape research. This model describes the relationship between three elements: farming practices, landscape patterns and natural resources. It can stimulate agronomists to deal with research issues in agricultural landscape dynamics and enhance the interdisciplinary integration of farming systems in wider landscape research.

On these premises, we discuss the main research issues that will benefit from an active involvement of agronomy, to understand, but also to assess landscape dynamics and to design relevant decision support systems.

\section{Keywords}

Conceptual model, Natural resources, Farming practices, Landscape patterns, 


\section{Introduction}

This manuscript is a collaborative work that arose from a debate on the role of agronomic concepts and approaches in landscape research. Two challenges underpin this debate. First, landscape research is called on to provide decisionmakers with relevant knowledge on agricultural landscape dynamics, in order to foster a more integrative support for multifunctional landscape design (Council of Europe 2000; Nassauer and Opdam 2008; Conrad et al. 2011). Second, agronomists increasingly have to deal with the positive and negative impacts of the farming systems on these landscape dynamics (Thenail and Baudry 2005; Groot et al. 2010; Pelosi et al. 2010; Wästfelt et al. 2012). It follows that agronomy needs to join forces with landscape research.

In this perspective paper we discuss how a part of agronomy is widening its focus addressing the landscape dynamics and how this new field contributes to deal with research issues on agricultural landscapes. We consider the landscape as the system where farmers interact with both natural and social resources through the management of their fields and of the associated features such as field margins and semi-natural habitat patches. Landscape research, especially from a landscape ecology perspective, appears to be focused on the characterization and understanding of landscape patterns and related ecological processes (e.g., Farina 2006). In the following paragraphs, we argue why and how agronomy can contribute to landscape research with a conceptual model suggesting a new perspective on farming practices as a crucial driver in the pattern-process relationships. 


\section{Why should agronomy contribute to landscape research?}

Farming accounts for the majority of human land use: pastures and crops took up $25.8 \%$ and $11.8 \%$, respectively, of the earth's land in 2009 (FAOSTAT 2009). It results that more than one third of the land on the planet is managed as farmland. Agronomy is the main discipline committed to the study of farming. Accordingly, this discipline is challenged to widen its conventional focus on farming practices so as to facilitate agriculture, not only for increasing production, but also to meet new social demands on farmland management (e.g., the protection of the environment and the upholding of cultural features).

Farming practices are performed on and interact with natural resources - mainly soil, water, and biodiversity - either at the field level (van Ittersum and Rabbinge 1997) or at wider scales (Veldkamp et al 2001; Dalgaard et al. 2003). Great advances in production techniques and the increasing availability of external inputs have replaced the main services that the local agroecosystems used to provide (e.g., soil fertility, water availability and pest control). However, these advances, fostered by a strong emphasis of agronomy on field performances, have resulted in a loss of interest in and knowledge on the interactions between farming practices and the surrounding natural system. In addition, some authors have highlighted that the mainstream agronomic literature have scarcely considered the role of the spatial configuration of the fields in farming (Cavazza 1996; Veldkamp et al. 2001; Hatfield 2007; Osty et al. 2008). Accordingly, agronomy has been urged for a greater consideration of a spatially explicit approach (White et al. 2002), especially so as to shift analysis from the field/farm scale toward wider levels (Leenhardt et al. 2010; Nesme et al. 2010). In brief, modern cropping system design has largely excluded 
the local context, eventually triggering severe environmental problems. This prompted society to request the following from agriculture and agronomy: first for a reduction of the impact on natural resources (e.g., Sheail 1995; Henle et al. 2008), and second for agro-environmental services to be provided (e.g., Viglizzo et al. 2004; Bastian et al. 2007; Brown and Schulte 2011). Recent agronomic approaches, while still seeking to improve crop and forage productions, are redesigning farming practices and trying to foster indeed the sustainable management of natural resources (Martin et al. 2006; Acevedo 2011). Nevertheless, to date, few agronomic studies have acknowledged the agricultural landscape as a complex socioenvironmental context that may influence field management (Deffontaines et al. 1995; van Mansvelt 1997; Groot et al. 2010; Pelosi et al. 2010; Valbuena et al. 2010). Broadly speaking, agronomy is a discipline aimed at delivering operative knowledge to the ultimate landscape managers: the farmers and their organizations (Deffontaines et al. 1995; Cavazza 1996; Benoît et al. 2007). Therefore, to enhance landscape research concerning the design and management of sustainable agricultural landscapes, we argue the need for an effective interdisciplinary approach that includes agronomic knowledge and tools. Operatively, this discipline will play a key role in integrating farming practices in the characterization of past landscape dynamics, in the assessment of contemporary landscape patterns, and in the design of future agricultural landscape scenarios. If agronomy fails to contribute its knowledge to agricultural landscape research, there is a real risk of misunderstanding and underestimating the role of farming in these landscape dynamics, which could lead to ineffective management decisions regarding these landscapes. 
The field of agronomy that can make innovative contributions to the analysis of agricultural landscape dynamics is referred to as "landscape agronomy". Landscape agronomy is the emerging perspective of agronomy focusing on the relations among farming practices, natural resources and landscape patterns, which are involved in the dynamics of agricultural landscapes. This new interest of agronomy for landscape issues and the new synergies that can emerge by collaboration with other disciplines involved in landscape research are the only way to develop sustainable agricultural landscapes for the future.

\section{What is our conceptual model?}

To explain the heart of landscape agronomy, we propose a conceptual model of the Agricultural Landscape Dynamics: ALaDyn (Fig. 1). This model will support us in discussing, in the next paragraph, how landscape agronomy deals with the characterization, assessment, and modeling of the relationships between farming systems and agricultural landscape dynamics.

We have elaborated this model from certain applications of landscape agronomy in research and education that have been discussed in earlier works (Benoît et al. 2007; Rapey et al. 2008; Rizzo 2009; Lazrak et al. 2010; Moonen et al. 2010; Marraccini et al. 2012). From these exploratory landscape agronomy experiences, we have found that there are three key elements that cannot be disentangled in the analysis of agricultural landscape dynamics: farming practices, natural resources, and landscape patterns.

These core items constitute the poles of the model. The relationships between the three poles are the major novelty of this model and show at the same time the importance of the development of landscape agronomy. The relationships we point- 
out are of two main types: (i) the farmers' perception of natural resources and/or landscape patterns, which they use to inform and attune their decision on practices; (ii) the response of landscape to the farming practices, observed either as direct impacts on it or as disturb to the dynamics of natural resources, as well as incidental

5 or fostered effects of the management. Hence, in the model we insist on the feedback loops between people and land for understanding landscape dynamics, in agreement with the call made by Verburg (2006).

The majority of landscape research mainly focuses on one or two of the poles, namely natural resources and landscape patterns. The model indicates instead that a full explanation of agricultural landscape dynamics must consider all three poles and therefore that farming practices need to be included if we want explain landscape dynamics appropriately. For example, we stress the need to consider the state of the natural resources and processes together with the spatial pattern in which they are distributed to understand or to improve the way farmers decide upon their farming practices (e.g., Acevedo 2011). Similarly, we consider that the analysis of the state of natural resources needs to account for how they are affected by the farming practices according to the local landscape patterns (e.g., Moonen and Bàrberi 2008). Finally, to be able to explain or to design agricultural landscape patterns, we need to know how they were affected by the interactions between farming practices and natural resources (e.g., Groot et al. 2010).

Therefore, ALaDyn introduces farming practices as the main levers with which to steer landscape dynamics. Farming practices are so pointed out as crucial activities in the management of spatial patterns and environmental processes occurring in agricultural landscapes, although they are rarely analyzed by the other disciplines involved in landscape research, particularly landscape ecology. 
\# Figure 1 approximately here \#

On the one hand farming practices are the activities chosen and performed by

5 farmers, mainly to improve the suitability of land for crops and livestock production. On the other hand farming practices are the elementary operations that affect the greatest part of the agricultural landscape dynamics through the choice and the allocation of the cropping systems. Sebillotte (1974) identified three choices of farmers that define the cropping systems over seasons and years: (i) the land cover, namely, the type of annual and multiannual crops or the type of grasslands; (ii) the temporal sequence of the different land covers and their allocation on the ensemble of farm land units (i.e., the fields, sometimes managed as a cluster), ordinarily over a given time-span; (iii) the crop management defined by the array of technical operations for each land cover, such as the type and timing of tillage, the quantity and type of fertilization, the time and density of sowing and so forth.

Although farming practices are chiefly performed in fields, they affect landscape dynamics through several trade-offs. Firstly, changes in farming practices shape various spatial and environmental characteristics of the landscape. It follows that farming practices can be oriented to design [sensu Nassauer and Opdam 2008; see also Gobster et al. 2007] new agricultural landscapes and intentionally-created landscape patterns. Moreover, natural resources can be actively managed through farming and are not only passively affected (Pelosi et al. 2010). Secondly, farming practices are responsible for the upholding of characteristic landscape features like hedges, terraces, channels, and roads (e.g., Thenail and Baudry 2004; Daugstad et al. 2006; Rizzo et al. 2007; Primdahl and Kristensen, 2011) as well as of the overall 
landscape care (Wästfelt et al. 2012). Therefore, ALaDyn lies at the crossroads between farming management and landscape design (Fig. 1).

From this brief presentation of ALaDyn becomes clear the two main contributions of landscape agronomy to research on agricultural landscape dynamics. On the one hand, this model clarifies that landscape agronomy explains landscape patterns in agricultural landscape as a configuration of fields designed by farming practices interacting with natural resources. On the other hand, it points out that landscape agronomy also considers the landscape patterns and the natural resources as drivers for farming practices. This cross-regard on landscape patterns makes a difference between landscape ecology and landscape agronomy. Landscape ecology mainly characterizes landscape patterns as observed research object to explain associated ecological processes and functions (Forman 1995; Farina 2006), while landscape agronomy characterizes and explains landscape patterns as a result of specific farming practices, as illustrated by pioneering landscape agronomic research (e.g., INRA-ENSSAA 1977; Sereni 1997) and recently highlighted by Wästfelt et al. (2012).

\section{How can landscape agronomy contribute to agricultural landscape research?}

In this section, we apply ALaDyn to analyze the specific contribution of landscape agronomy to crucial issues in agricultural landscape research. The first issue is to enhance the characterization of the relationship between current landscapes patterns and farming practices (4.1); the second issue is to clarify the role of farming practices in assessing landscape patterns (4.2); and the third issue is to improve the design of future agricultural landscapes (4.3). 


\subsection{Characterizing landscape patterns as a result of farming practices}

The structure of an agricultural landscape and its ecosystem services is largely defined by the agricultural practices that have been performed and that are constantly renewed by farmers. Farming practices can be viewed as determinants of the landscape patterns, and their potential impact on natural resources and cultural features has been evaluated (Egoz et al. 2001; Mignolet 2008; Rizzo 2009; Galli et al. 2010; Jacopin 2011). Farming practices have also been identified as the crucial pivot between the local landscape identity and global agro-industrial trajectories (e.g., Jarosz and Qazi 2000; Jackson 2008). These two examples highlight the different ways in which patterns and resources in agricultural landscapes are affected by past and current farming practices. Accordingly, we deem that the systematic inclusion of the study of farming practices into landscape research would help to increase our knowledge of the relationships between landscape patterns and agro-ecosystem services, such as the preservation of functional biodiversity (Moonen and Bàrberi 2008) or the improvement of spatial heterogeneity (Brandt et al. 2012), and would allow us to steer these services in future landscapes. Recent research on farming practices has highlighted the need to collect a large amount of data in order to characterize the real practices and choices of farmers over long time-spans (to overcome seasonal variability) and wide regions (to skip local specificities) (e.g., Mignolet 2008; Leenhardt et al. 2010). Landscape agronomy, by considering the relationships between landscape patterns, farming practices, and natural resources (see the ALaDyn model in Fig. 1), can help to enhance the relevance of these timeconsuming surveys for interdisciplinary landscape research. 


\subsection{Understanding farming practices to assess current landscape patterns}

Landscape dynamics occurring in today's agricultural landscapes are mainly managed at the field level. Classic agronomy has focused on the field as the space where farming practices are performed, thus identifying it as an interface with ecology and other disciplines (Deffontaines 1991; Le Ber and Benoît 1998; Thenail et al. 2009; Pelosi et al. 2010). Indeed, the field defined by agronomists seems to give an operational translation to the "landscape unit," which Moss (2000) identified as the critical element with which socioeconomic and cultural factors interact across heterogeneous agricultural landscapes.

To improve on the classic agronomic approach, landscape agronomy moves the focus from the field to the spatial configuration of fields as the crucial concept for assessing and managing the three poles of agricultural landscape dynamics (Fig. 1) and thereby meeting new societal demands (Benoît et al. 2007). The spatial configuration includes both the topological characteristics of an "ensemble" [sensu Antrop 1997] of fields (e.g., their shape, size, and location) and their spatial and functional relationship with other landscape features (e.g., irrigation and drainage channels, hedgerows, and field margins). These configurations are further influenced by natural resources and local topographical conditions. For instance, water accessibility or proximity to the farmstead could constrain or enhance farming practices, thus shaping field configurations accordingly (Morlon and Benoît 1990; Thenail and Baudry 2004; Thenail et al. 2009).

The issue at stake is to select the criteria to aggregate fields into landscape patterns when fostering a salient assessment and an improved management of landscape dynamics. A first criterion could be to focus on the environmental 
resources, such as water, thus characterizing the spatial configuration of farmed fields at the watershed level (Vogt et al. 2002; Mignolet et al. 2004). Another criterion could be the field aggregation designed by a legal framework, such as in the case of regulations for traditional or quality food with a Protected Geographical Status (Vollet et al. 2008). Another criterion could be plot aggregation as a function of recurring crop rotations (Thenail et al. 2009; Lazrak et al. 2010). The relevance of crop rotations is still poorly considered (Leenhardt et al. 2010), even though highly consistent with the assessment of farming practices over wide regions. In general, the main advantage of these criteria should be to overcome the vagueness in the definition of single field limits, which change according to seasonally evolving practices (Morlon 2005) and may differ according to the approach used for their definition (Nesme et al. 2010). In addition the aggregation of fields according to different criteria would tackle the call for an interdisciplinary and multi-scalar approach in agronomy made so far by some authors (Moss 2000; Dalgaard et al. 2003, Acevedo 2011).

By introducing farming practices as a crucial element for understanding the spatial configuration of landscapes, landscape agronomy complements the knowledge of landscape patterns provided by landscape ecology. In particular, landscape agronomy can help explain patterns as "regularities" shaped by farming practices (e.g., Lazrak 2012). In other words, it is the farmers' decision making when choosing their farming practices that determines the spatial configuration of fields [perceived and measured as landscape patterns]. Shaller et al. (2012) have demonstrated that today's landscape spatial organization can be explained by coupling decision-making process modeling ("rules") and stochastic modeling ("regularities"). In this way, they have shown how the emerging landscape agronomy approach can make original 
contributions to the interpretation and explanation of agricultural landscape dynamics relating farming practices and landscape patterns.

\subsection{Improving tools to design future agricultural landscapes}

The main contribution of landscape agronomy to improve the design of future landscapes is to integrate appropriate descriptors of the farming practices and their evolutions in the assessment and scenarios of landscape dynamics, so as to meet the increasing societal demands for multifunctional landscapes (Beuret 2002;

Gobster et al. 2007; Gaucherel et al. 2009; Pinto-Correia and Breman 2009; Groot et al. 2010; Domon 2011; Brandt et al. 2012).

More generally, landscape agronomy will contribute to landscape research also by integrating the goals of agricultural production into the multiple objectives of the landscape design and management. Such a goal has been identified as a priority for the agricultural policy agenda itself (Beddington et al. 2012; Wästfelt et al. 2012). For this, landscape agronomy may for instance assess and operationalize future landscape designs on the knowledge about farmers' entrepreneurial goals, in a way they could more easily master and discuss the proposed scenarios with the other local actors.

Recent advances in agronomy have largely taken advantage of the availability of spatial data and improved measurements of crops performances to address spatially attuned practices (such as the precision agriculture approach) at the field/farm level (e.g., Schellberg et al. 2008; Oliver et al. 2010; Lamanda et al. 2012). By mean of ALaDyn (fig. 1) we spur research on agriculture (uppermost the studies focusing on farming practices) to develop tools to stress and integrate the diversity of placebased and contextual challenges/opportunities over larger scales. For example, landscape agronomic methods should address the (re)design of farming systems 
assessing crop rotations and crop management for the impacts on natural resources given the specific landscape patterns into which they will be proposed. In this regard, few researchers (e.g., Grilli 2008, Groot et al. 2010, Lovell et al 2010) have tested an iterative "sketch design" process of agricultural landscape management from the field or feature level to wider field configurations and regional level that means closer to scales at which landscape patterns are-designed.

Future agricultural landscape dynamics will likely be driven by conflicts in land use (e.g., energy versus food production) and constrained by the availability of resources (e.g., water shortage due to climate change) (see Acevedo 2011). Accordingly, the relationships between farming practices, natural resources and landscape patterns will be further stressed and even exacerbated on a place-based perspective. Therefore, the role of agronomists could become crucial to properly elicit and assess the spatial diversity and impacts of farming practices on the overall management of agricultural landscapes.

\section{Conclusions and perspectives}

The relationships between farming practices and landscape dynamics are still poorly explored despite the conflicting expectations on land use stressed by land change science (Rindfuss et al. 2004; Turner et al. 2007; Rounsevell et al. 2012) and concerns over the loss of agricultural land (Dramstad and Fjellstad 2011). In this context, the underpinning idea of landscape agronomy is that research on agricultural landscape should integrate both the influence of the landscape on farming practices, only partly explored by some authors (e.g., Primdahl 1999; Busck 2002; Claessens et al. 2009), and the role of the farmer as actor shaping patterns and processes observed from a landscape ecology perspective (e.g., Baudry et al. 2003; Burel and 
Baudry 2005). From this viewpoint, we see landscape agronomy as fertile ground for the interaction between agronomy and landscape ecology seeking an agreement on shared concepts (Fig. 1), as well as with the wide range of disciplines classically involved in landscape research such as geography, ecology, planning, and architecture. Landscape agronomy is intended to include issues raised, for instance, in policies, by extensionists and so forth, about the roles of farmers in the management of the landscape. This management concerns the natural resources and the services expected by societies at the landscape level, such as attractiveness for leisure, preservation of cultural features, tourism, etc.

Our knowledge and experience as agronomists allowed us to define a conceptual model of agricultural landscape dynamics (Fig. 1) whose main novelty is the integration of farming practices as a core item with which to understand and consequently steer landscape dynamics. We acknowledge to ALaDyn three roles. First, it is meant as a conceptual basis to orient research on agricultural landscape dynamics defining a relative positioning according to the integrative perspective of landscape agronomy. Second, it could work as template to develop research tools and scenarios that include the crucial components and relations (poles and arrows in Fig. 1) of landscape dynamics in farmed lands. Third, it could be used as reference grid to highlight gaps in the development of agronomic research, especially concerning the spatial patterns of farming practices.

In conclusion, landscape agronomy is for us closely related to the research on agricultural landscape dynamics because its principal aim is to deal with the reciprocal influence between the landscape dynamics and the farmers. In addressing this influence we draw attention to some critical questions. How do farmers affect the landscape through their practices? What are the levers of action to support or 
reorient these practices? Are the policies appropriate? How are farmer practices influenced by landscape features? Are the proposals for new multifunctional landscapes sustainable to combine practices for landscape management and practices for production management? Hence, who is working on this?

5 We hope to initiate a constructive dialogue between agronomists and other landscape scientists in order to strengthen the agronomic contribution to landscape research and to formulate a shared understanding of the role of agronomy in research on landscape dynamics. 


\section{Acknowledgments}

We are very grateful to our colleagues who contributed their ideas and comments to earlier versions of the paper, in particular to Paolo Bàrberi, Nicola Silvestri, and Patrick Caron. We would also like to warmly thank the students and stakeholders who participated in the two winter schools on landscape agronomy in 2007 and 2009 and the teaching staff and their institutions: the former Land Lab department (now Institute of Life Sciences) of the Scuola Superiore Sant'Anna which financed the schools, and the Science for Action and Development (SAD) department of Institut National de la Recherche Agronomique. We acknowledge the financial support of the

10 French ANR programs COPT, BiodivAgrim, the European FP7 project RUFUS and the Rhin-Meuse Water Agency. The authors also wish to sincerely thank the anonymous reviewers from whom they received useful criticism.

\section{References}

Acevedo MF (2011) Interdisciplinary progress in food production, food security and environment research. Environmental Conservation 38:151-171

Antrop M (1997) The concept of traditional landscapes as a base for landscape evaluation and planning. The example of Flanders Region. Landscape and Urban Planning 38:105-117

Bastian O, Corti C, Lebboroni M (2007) Determining environmental minimum requirements for functions provided by agro-ecosystems. Agronomy for Sustainable Development 27:279-291

Baudry J, Burel F, Aviron S, Martin M, Ouin A, Pain G, Thenail C (2003) Temporal variability of connectivity in agricultural landscapes: do farming activities help? Landscape Ecology 18:303-314

Beddington J, Asaduzzaman M, Clark M, Fernández-Bremauntz A, Guillou MD, Howlett DJB, Jahn MM, Lin E, Mamo T, Negra C, Nobre CA, Scholes RJ, Van Bo N, Wakhungu J (2012) What Next for Agriculture After Durban? Science 335:289-290 Thenail C, Lardon S, Rapey H, Marraccini E, Le Ber F, Meynard JM (2007) Landscape designed by farming systems: a challenge for landscape agronomists in Europe. In: Donatelli M, Hatfield J, Rizzoli A (eds) Farming Systems Design 2007, Int. Symposium on Methodologies on Integrated Analysis on Farm Production Systems, Catania (Italy), book 1 - Farm-regional scale design and 
improvement, pp 137bis-138bis. Available from

http://www.iemss.org/farmsys07/uploads/Main/Farm_regional_scale_CD.pdf. Accessed September 2012

Beuret JE (2002) À qui appartient le paysage? (To whom does the landscape belong?) Nature Sciences Sociétés 10:47-53

Brandt J, Christensen A, Svenningsen S, Holmes E (2012) Landscape practise and key concepts for landscape sustainability. Landscape Ecology (in press) doi: 10.1007/s10980-012-9777-5

Brown PW, Schulte LA (2011) Agricultural landscape change (1937-2002) in three townships in lowa, USA. Landscape and Urban Planning 100:202-212

10 Burel F, Baudry J (2005) Habitat quality and connectivity in agricultural landscapes: the role of land use systems at various scales in time. Ecological Indicators 5:305-313

Busck AG (2002) Farmers' landscape decisions: relationships between farmers' values and landscape practices. Sociologia Ruralis 42:233-249

Cavazza L (1996) Agronomia aziendale e agronomia del territorio. Rivista di Agronomia 30(3):310-319

Claessens L, Schoorl JM, Verburg PH, Geraedts L, Veldkamp A (2009) Modelling interactions and feedback mechanisms between land use change and landscape processes. Agriculture, Ecosystems and Environment 129:157-170

Council of Europe (2000) European Landscape Convention, Treaty Series n.176

Conrad E, Christie M, Fazey I (2011) Is research keeping up with changes in landscape policy? A review of the literature. Journal of Environmental Management 92:2097-2108

Dalgaard T, Hutchings NJ, Porter JR (2003) Agroecology, scaling and interdisciplinarity. Agriculture, Ecosystems and Environment 100:39-51

Daugstad K, Rønningen K, Skar B (2006) Agriculture as an upholder of cultural heritage? Conceptualizations and value judgements - A Norwegian perspective in international context. Journal of Rural Studies 22:67-81

Deffontaines JP (1991) L'agronomie, science du champ. Le champ, lieu d'interdisciplinarité: de l'écophysiologie aux sciences humaines. Agronomie 11:581-591 
Deffontaines JP, Thenail C, Baudry J (1995) Agricultural systems and landscape patterns: how can we build a relationship? Landscape and Urban Planning 31:3-10

Domon G (2011) Landscape as resource: Consequences, challenges and opportunities for rural development. Landscape and Urban Planning 100:338-340

Dramstad WE, Fjellstad WJ (2011) Landscapes: Bridging the gaps between science, policy and people. Landscape and Urban Planning 100:330-332

Egoz S, Bowring J, Perkins HC (2001) Tastes in tension: form, function, and meaning in New Zealand's farmed landscapes. Landscape and Urban Planning 57:177-196

FAOSTAT (2009) Available online at. http://faostat.fao.org/site/377/DesktopDefault.aspx?PagelD=377\#ancor. Accessed 7 Oct 2011

Farina A (2006) Principles and methods in landscape ecology: toward a science of landscape. Springer, Dordrecht

Forman RTT (1995) Land mosaics: the ecology of landscapes and regions. Cambridge University Press, Cambridge

Galli M, Bonari E, Marraccini E, Debolini M (2010) Characterisation of Agri-Landscape Systems at a Regional Level: A Case Study in Northern Tuscany. Italian Journal of Agronomy 5:285-294

Gaucherel C, Griffon S, Misson L, Houet T (2009) Combining process-based models for future biomass assessment at landscape scale. Landscape Ecology 25:201-215

Gobster PH, Nassauer JI, Daniel TC, Fry G (2007) The shared landscape: what does aesthetics have to do with ecology? Landscape Ecology 22:959-972

Grilli MP (2008) An area-wide model approach for the management of a disease vector planthopper in an extensive agricultural system. Ecological Modelling 213: 308-318

Groot JCJ, Jellema A, Rossing WAH (2010) Designing a hedgerow network in a multifunctional agricultural landscape: Balancing trade-offs among ecological quality, landscape character and implementation costs. European Journal of Agronomy 32:112-119

Hatfield JL (2007) Beyond the Edge of the Field. https://www.agronomy.org/about-society/presidentsmessage/archive/13. Accessed 27 March 2012 
Henle K, Alard D, Clitherow J, Cobb P, Firbank L, Kull T, McCracken D, Moritz RFA, Niemelä J,

Rebane M, Wascher D, Watt A, Young J (2008) Identifying and managing the conflicts between agriculture and biodiversity conservation in Europe-A review. Agriculture, Ecosystems and Environment 124:60-71

INRA-ENSSAA (1977) Pays Paysans Paysages dans les Vosges du sud. INRA, Paris

Jackson LL (2008) Who "Designs" the Agricultural Landscape? Landscape Journal 27:23-40

Jacopin R (2011) Paysages et pratiques des agriculteurs dans le Sud du Plateau Lorrain: logiques d'organisation et effets sur l'environnement. PhD thesis, Université Nancy II

Jarosz L, Qazi J (2000) The geography of Washington's world apple: global expressions in a local landscape. Journal of Rural Studies 16:1-11

Lamanda N, Roux S, Delmotte S, Merot A, Rapidel B, Adam M, Wery J (2012) A protocol for the conceptualisation of an agro-ecosystem to guide data acquisition and analysis and expert knowledge integration. European Journal of Agronomy 38:104-116

Lazrak EG, Mari J-F, Benoît M (2010) Landscape regularity modelling for environmental challenges in agriculture. Landscape Ecology 25:169-183

Lazrak EG (2012) Fouille de données stochastique pour la compréhension des dynamiques temporelles et spatiales des territoires agricoles. Contribution à une agronomie numérique des territoires. PhD thesis, Université de Lorraine

Le Ber FL, Benoît M (1998) Modelling the spatial organization of land use in a farming territory. Example of a village in the Plateau Lorrain. Agronomie 18:103-115

Leenhardt D, Angevin F, Biarnès A, Colbach N, Mignolet C (2010) Describing and locating cropping systems on a regional scale. A review. Agronomy for Sustainable Development 30:131-138

Lovell ST, DeSantis S, Nathan CA, Olson MB, Méndez VE, Kominami HC, Erickson DL, Morris KS, Morris WB (2010) Integrating agroecology and landscape multifunctionality in Vermont: An evolving framework to evaluate the design of agroecosystems. Agricultural Systems 103:327-341

Martin P, Joannon A, Mignolet C, Souchère V, Thenail C (2006) Systèmes de culture et territoires: cas des questions environnementales. In: Doré T, Le Bail M, Martin P, Ney B, Roger-Estrade J (eds) L’agronomie aujourd'hui. Éditions Quae, Versailles, pp 253-283 
Marraccini E, Rizzo D, Debolini M, Planchat C, Toiller A (2012) Contribution of agronomy to land management issues - A Comparison of five interdisciplinary PhD theses. In: Producing and reproducing farming systems, Proceedings of the $10^{\text {th }}$ European IFSA Symposium, Aarhus, Denmark, 10 pages. Available at http://ifsa.boku.ac.at/cms/fileadmin/Proceeding2012/IFSA2012_WS5.3_Marracciniet.pdf. Accessed September 2012

Mignolet C, Schott C, Benoît M (2004) Spatial dynamics of agricultural practices on a basin territory: a retrospective study to implement models simulating nitrate flow. The case of the Seine basin. Agronomie 24:219-236

10 Mignolet C (2008) Modélisation de l'organisation spatiale des systèmes agricoles et de son évolution dans des démarches d'appui au développement. PhD thesis, Institut des Sciences et Industries du Vivant et de l'Environnement (Agro Paris Tech)

Moonen AC, Bàrberi P (2008) Functional biodiversity: An agroecosystem approach. Agriculture Ecosystems and Environment 127:7-21 Debolini M, Bàrberi P, Bonari E (2010) A winter school in landscape agronomy and the synergies it created. In: Darnhofer I, Grötzer M (eds) Building sustainable rural futures. The added value of systems approaches in times of change and uncertainty. University of Natural Resources and Applied Life Sciences, Vienna (AUT), pp 2176-2183. Available at http://ifsa.boku.ac.at/cms/fileadmin/Proceeding2010/2010_WS5.4_Moonen.pdf. Accessed September 2012

Morlon P (2005) La dimension spatiale des pratiques agricoles: une approche agronomique. In: Laurent C, Pascal T (eds) Agricultures et territoires. Lavoisier, Paris, pp 175-190

Morlon P, Benoît M (1990) Étude méthodologique d'un parcellaire d'exploitation agricole en tant que système. Agronomie 6:499-508

Moss MR (2000) Interdisciplinarity, landscape ecology and the 'Transformation of Agricultural Landscapes'. Landscape Ecology 15:303-311 
Nassauer JI, Opdam P (2008) Design in science: extending the landscape ecology paradigm. Landscape Ecology 23:633-644

Nesme T, Lescourret F, Bellon S, Habib R (2010) Is the plot concept an obstacle in agricultural sciences? A review focussing on fruit production. Agriculture, Ecosystems and Environment 138:133-138

Oliver YM, Robertson MJ, Wong MTF (2010) Integrating farmer knowledge, precision agriculture tools, and crop simulation modelling to evaluate management options for poor-performing patches in cropping fields. European Journal of Agronomy 32:40-50

Osty PL, Le Ber F, Lieber J (2008) Raisonnement à partir de cas et agronomie des territoires. Revue d'anthropologie des connaissances 2:169-193. Available at www.cairn.info/revue-anthropologiedes-connaissances-2008-2-page-169.htm. Accessed September 2012

Pelosi, C, Goulard M, Balent G (2010) The spatial scale mismatch between ecological processes and agricultural management: Do difficulties come from underlying theoretical frameworks? Agriculture, Ecosystems and Environment 139:455-462

Pinto-Correia T, Breman B (2009) New roles for farming in a differentiated countryside: the Portuguese example. Regional Environmental Change 9:143-152

Primdahl J (1999) Agricultural landscapes as places of production and for living in owner's versus producer's decision making and the implications for planning. Landscape and Urban Planning $46: 143-150$

20 Primdahl J, Kristensen LS (2011) The farmer as a landscape manager: Management roles and change patterns in a Danish region. Geografisk Tidsskrift-Danish Journal of Geography 111:107116. Available at http://rdgs.dk/djg_article_details.asp?site=djg\&art_id=1532. Accessed September 2012

Rapey H, Lardon S, Galli M, Moonen AC, Benoît M, Thenail C, Bàrberi P, Caron P, Marraccini E, Rizzo D, Bonari E (2008) Experiences from a winter school on landscape agronomy: stakes, difficulties, perspectives. In: Dedieu B, Zasser-Bedoya S (eds) Empowerment of the rural actors: A renewal of the farming systems perspective. INRA-SAD, Clermont-Ferrand, France, pp 999-1004. 
Available at http://ifsa.boku.ac.at/cms/fileadmin/Proceeding2008/2008_WSS_07_Rapey.pdf. Accessed September 2012

Rindfuss RR, Walsh SJ, Turner B, Fox J, Mishra V (2004) Developing a science of land change: Challenges and methodological issues. PNAS 101(39):13976-13981

Rizzo D (2009) Landscape-agronomic analysis in the agro-environmental fragility assessment of a terraced landscape (in Italian). PhD thesis, Scuola Superiore Sant'Anna

Rizzo D, Galli M, Sabbatini T, Bonari E (2007) Terraced landscapes characterization. Developing a methodology to map and analyze the agricultural management impacts (Monte Pisano, Italy). Revue Internationale de Géomatique 17:431-447

Rounsevell MDA, Pedroli B, Erb KH, Gramberger M, Busck AG, Haberl H, Kristensen S, Kuemmerle T, Lavorel S, Lindner M, Lotze-Campen H, Metzger MJ, Murray-Rust D, Popp A, Pérez-Sobab M, Reenberg A, Vadineanu A, Verburg PH, Wolfslehner B (2012) Challenges for land system science. Land Use Policy 29:899-910

Schaller N, Lazrak EG, Martin P, Mari JF, Aubry C, Benoît M (2012) Combining farmers' decision rules and landscape stochastic regularities for landscape modelling. Landscape Ecology 27:433-446

Schellberg J, Hill MJ, Gerhards R, Rothmund M, Braun M (2008) Precision agriculture on grassland: Applications, perspectives and constraints. European Journal of Agronomy 29:59-71

Sebillotte M (1974) Agronomie et agriculture. Essai d'analyse des tâches de l'agronome. Cahiers Orstom 24:3-25

Sereni E (1997) History of the Italian Agricultural Landscape. Princeton University Press, Princeton

Sheail J (1995) Nature protection, ecologists and the farming context: A U.K. historical context. Journal of Rural Studies 11:79-88

Thenail C, Baudry J (2004) Variation of farm spatial land use pattern according to the structure of the hedgerow network (bocage) landscape: a study case in northeast Brittany, France. Agriculture Ecosystems and Environment 101:53-72

Thenail C, Baudry J (2005) Farm riparian land use management: driving factors and tensions between technical and ecological functions. Environmental Management 36: 640-653 
Thenail C, Joannon A, Capitaine M, Souchère V, Mignolet C, Schermann N, Di Pietro F, Pons Y, Gaucherel C, Viaud V, Baudry J (2009) The contribution of crop-rotation organization in farms to crop-mosaic patterning at local landscape scales. Agriculture, Ecosystems and Environment $131: 207-219$

5 Turner BL, Lambin EF, Reenberg A (2007) The emergence of land change science for global environmental change and sustainability. PNAS 104:20666-20671

Valbuena D, Verburg PH, Veldkamp A, Bregt AK, Ligtenberg A (2010) Effects of farmers' decisions on the landscape structure of a Dutch rural region: An agent-based approach. Landscape and Urban Planning 97:98-110

10 van Ittersum MK, Rabbinge R (1997) Concepts in production ecology for analysis and quantification of agricultural input-output combinations. Field Crops Research 52:197-208

van Mansvelt JD (1997) An interdisciplinary approach to integrate a range of agro-landscape values as proposed by representatives of various disciplines. Agriculture, Ecosystems and Environment $63: 233-250$

Veldkamp A, Kok K, De Koning GHJ, Schoorl JM, Sonneveld MPW, Verburg PH (2001) Multi-scale system approaches in agronomic research at the landscape level. Soil and Tillage Research $58: 129-140$

Verburg P (2006) Simulating feedbacks in land use and land cover change models. Landscape Ecology 21:1171-1183

Viglizzo EF, Pordomingo AJ, Castro MG, Lértora FA, Bernardos JN (2004) Scale-dependent controls on ecological functions in agroecosystems of Argentina. Agriculture, Ecosystems and Environment $101: 39-51$

Vogt KA, Grove M, Asbjornsen H, Maxwell KB, Vogt DJ, Sigurdardotter R, Larson BC, Schibli L, Dove M (2002) Linking ecological and social scales for natural resource management. Integrating 25 landscape ecology into natural resource management. Cambridge University Press, Cambridge, pp $143-175$ 
The final publication Benoît, Rizzo et al. (2012) on Landscape ecology 10(27): 1385-1394 is available at http://link.springer.com/article/10.1007/s10980-012-9802-8

Vollet D, Candau J, Ginelli L, Michelin Y, Ménadier L, Rapey H, Dobremez L (2008) Landscape elements: Can they help in selling "Protected Designation of Origin" products? Landscape Research 33:365-384

Wästfelt A, Saltzman K, Gräslund Berg E, Dahlberg A (2012) Landscape care paradoxes: Swedish landscape care arrangements in a European context. Geoforum (in press) doi: 10.1016/j.geoforum.2012.03.004

White JW, Corbett JD, Dobermann A (2002) Insufficient geographic characterization and analysis in the planning, execution and dissemination of agronomic research? Field Crops Research 76:45-54 


\section{Captions}

Fig. 1. Our conceptual model of agricultural landscape dynamics (ALaDyn), structuring the relationships between natural resources, landscape patterns, and farming practices.

\section{Suggested citation format}

- within the text:

Benoît, Rizzo et al. (2012)

10

- in the reference list:

Benoît M, Rizzo D, Marraccini E, Moonen AC, Galli M, Lardon S, Rapey H, Thenail C, Bonari E (2012) Landscape agronomy: a new field for addressing agricultural landscape dynamics. Landscape Ecology 10(27):1385-1394. doi: 10.1007/s10980012-9802-8 